\title{
THE SOCIOLOGICAL EXPLANATION OF INDONESIAN MUSLIM FAMILY Continuity and Change
}

\author{
JM. Muslimin | UIN Syarif Hidayatullah Jakarta - Indonesia \\ jm.muslimin@uinjkt.ac.id
}

\begin{abstract}
The study indicates that there is a tendency for family characteristics, functions, and structures to be questioned. Many people, for example, would consider unmarried couples, single mothers or single fathers, and homosexual couples to be the same legitimate expressions of family units. However, Indonesian Muslim family takes a more conservative stance, arguing that the family is a divinely inspired institution, with marriage as the starting point of its differentiation. The article explores what the family means for Muslims in general: its normative philosophy, its implementtation in general and the challenges that will be faced. The goal is to offer an introduction to keywords and a general map of the problem. Some cases are presented as explanatory tools. The used method is library research by utilizing the results of previous research and then carried out contextualization in the Indonesian situation. There are several findings and one of the most important one is that within Indonesian muslim context, there are still several values upheld quite conventionally. Even the very basic of family issues that is the definition remains quite conservative and this is legally stated in several policies including the 1974 marriage law. In addition, there are also several interesting changes occur within Indonesian sociology of family and among the issues are roles divisions, divorces and arranged marriages.
\end{abstract}

Keywords: Muslim family, sociological explanation, marriage law

\section{Introduction}

The issue of marriage and family has now become a public issue. In various countries, this issue has even become part of policies and 
regulations. China for example, has issued a one-child policy since 1970 's in order to prevent population growth out of control. ${ }^{1}$ France initiated Day Care as a consequence of working French women and the decline of the average woman's first pregnancy. ${ }^{2}$ In addition, in Russia, the government even published "Russian Family Policy Conception for the Period until 2025". The policy was triggered by a crisis in Russian families in the late 1990s and early 2000s which includes the effects of low fertility rates, a prevalence of divorce and weak family ties. ${ }^{3}$

In various countries, family terminologies are believed to be the smallest social unit that plays an important role in the formation of national character. The family was even agreed upon as a major component in the Sustainable Development Goals (SDGs). ${ }^{4}$ Thus, the relationship of marriage ${ }^{5}$ as an institution that gives birth to a family can no longer be seen as merely an institution of biological reproductive sexuality but an important clue to the integration and social coherence of society. Jocelyn Newman says that there are many important points in family life that put extra pressure on every relationship. Childbirth, death of family members, children's life cycles, parents work or are forced to lose their jobs, elderly family members, sick or disabled become a number of issues that arise in family resilience. ${ }^{6}$ That is why Ahmad Mubarok stated that family success involves many determinants not only in two married couples, but in the environment, paradigms and habits that live in the community. ${ }^{7}$

1 Han Suyin, "Family planning in China," Development \& Civilizations, 47 (1972): pp. 102-109.

2 Genevieve Balleyguier, "What is the Best Mode of Day Care for Young Children: A French study," Early Child Development and Care 33, 1-4 (1988): pp. 41-65.

3 Zhanna Chernova, "New Pronatalism?: Family Policy in Post-Soviet Russia," Region: Regional Studies of Russia, Eastern Europe, and Central Asia 1, 1 (2012): pp. 75-92.

4 Barbara Dockalova, et al., Sustainable Development Goals and Family Planning 2020 (London: IPPF, 2016).

5 Marriage relations are a universal pattern of human social relations that exist in every culture and subculture throughout the world. Called universal, because substantially agreed marriages are marriages between men and women legalized by the state, although this issue also accommodates men and women who live together without marriage and same-sex relations.

${ }^{6}$ Jocelyn Newman, Discussion Paper: The Challenge of Welfare Dependency in the 21st Century (Canberra: Department of Family and Community Services, 2000)

7 Achmad Mubarok, Psikologi Keluarga, dari Keluarga Sakinah hingga Keluarga Bangsa 
Although the definition of family has undergone development in various countries and this includes the recognition of forms of samesex marriage and or family with adopted children and so on, the definition in the context of the Indonesian Islamic community seems to remain the same. Families are limited by the definition that develops in Indonesia, especially those that are in line with Islamic sharia. Terminologically, the family in Islam refers to the word usrah, which, if traced in the al-Qur'an, appears in the word "J-ا-س", contained in QS al-Insān verse 28 and interpreted by the joints of the body. Referring to the syntax, in Lisanul 'Arab, usrah is defined as a group of people who are structured and tasked with stabilizing and developing the community. ${ }^{8}$ Outside the word, usrah, there are also the words 'ashirah, $a b l$, and rabt which also represent the family. In general, the whole word explains the meaning that family is the first social unit in a society formed from legitimate male and female marriages, and from which all humanity is preserved.

Sociologically, families are formed into various types. There is a socalled nuclear family, which consists of father, mother and child siblings. There is also a chain family (Serial Family) consisting of women and men who are married more than once and are one nuclear family. In addition, there are also single families (Serial Family) and these are families that only consist of a father or mother with their children. Interestingly, there is also a composition family (Composite), which is a family whose marriage is polygamous and lives together. ${ }^{9}$

From legal point of view, based on Law Number 10 of 1992 concerning the Development of Population and Prosperous Families in Indonesia, ${ }^{10}$ the family is the smallest unit in a society consisting of a husband, wife or husband and wife and children or father and children or mother and child. Meanwhile, based on Law Number 1 of 1974 concerning Marriage, it is defined that marriage is a physical and spiritual bond between a man and a woman as a husband and wife ${ }^{11}$. In

(Jakarta: PT. Bina Rena Pariwara, 2005).

8 Muhammad ibn Mukarram ibn `Alī, ibn Manzūr, Lisan al-arab (Beirut, Lebanon: Al Dar al-Misriyya Li-l-ta'lif wa-l-tarhim, 1975).

9 Frank D. Cox and Kevin Demmitt, Human Intimacy: Marriage, The Family, And Its Meaning (Wadsworth: Cengage Learning, 2013),

10 Law 10/1992 on Population Growth and the Development of Prosperous Family.

11 Law $1 / 1974$ on Marriage. 
this regards, the way family and marriage are defined results in limiting the definition of family within Indonesian context. A family must be based on a marriage recognized by the State and thus a family without marriage cannot be recognized as a family.

Referring to the juridical definition, the family in Indonesia is not seen as merely a relationship between men and women; rather, it is seen as a legalized born-out bond. That is why family development is also part of national development issues.12 Law No. 10 of $1992^{13}$, explains about Family Resilience as a tool to measure how far the family has carried out roles, functions, duties, and responsibilities in realizing the welfare of its members. In 2009, Law Number 52 concerning the Development of Population and Family Development ${ }^{14}$ even stated that the power of national development was rooted in the family element since it is a micro-community within the society. Thus, family prosperity was the basic foundation for the strength and sustainability of development. Conversely, vulnerable and scattered families weaken the foundation of the life of the state community.

One of the most striking features of Muslim society is the importance of being attached to the family. Family units are considered to be the main healthy and balanced foundation of society. ${ }^{15}$ This highlights the difference from those found in individual-centered cultures.

According to Dhami and Sheikh, the Normative Platform for Conventional Islamic Families revolves around: ${ }^{16}$ (a) the family forms the basic building blocks of Muslim society. Despite the many pressures it faces, family institutions remain strong. However, the

\footnotetext{
12 Juridically, family resilience has started from Law Number 10 of 1992 concerning the Development of Population and Development of the Prosperous Family which states that "Family resilience serves as a tool to measure how far the family has carried out roles, functions, duties, responsibilities in realizing prosperity its members". The Government Regulation of the Republic of Indonesia Number 21 of 1994 concerning the Implementation of the Development of the Prosperous Family strengthens the concept by stating that the family as the smallest unit in society has a very important role in national development.

13 Law 10/1992 on Population Growth and the Development of Prosperous Family.

14 Law 52/2009 on Population Growth and the Development of Prosperous Family.

15 Abdur Rahman Doi, Shariah: The Islamic law (London: Ta Ha Publishers, 1984).

16 Sangeeta Dhami and Aziz Sheikh, "The Muslim family: predicament and promise," Western Journal of Medicine 173, 5 (2000): pp. 352-356.
} 
future of the extended family, however, is under great threat; (b) genital mutilation in women is common among Muslim and nonMuslim women from Africa in particular; (c) marriage forms the only basis for sexual relations and parents; (d) Islamic law generally prohibits the use of contraception, praising the goodness of large families, but there seems to be a tendency to be a small family, at least lately; (e) some social problems such as sexually transmitted infections, cervical cancer, and unwanted pregnancies can be reduced by developing vehicles to strengthen traditional Muslim family structures.

\section{Islamic Family}

\section{Wedding}

In Islam, husband and wives are supposed to protect one another. It is stated quite beautifully in Qur'an as follows meaning: "they are clothes for you, and you are also clothes for them ..." (Al-Baqarah: 187).

This concise parable of the Qur'an summarizes the main goals of marriage which is to provide warmth, comfort, and protection and to beautify. In the vision of Islam, children have the right to be understood and raised in a stable and safe environment; marriage is considered to provide such an environment. Conversely, celibacy and extramarital sex are not recommended because it is considered a negative behavior that is not conducive to a healthy society. ${ }^{17}$

In many cases, marriage is considered a union of two families. In fact, it is also not a peculiar phenomenon that parents usually arrange marriages. Even though the free consent of the two brides is important, coercion of parents is often strong.

Despite the fact that some parents clearly begin to understand the problems of such coercion to their children's marriage, the practice of arranged marriages continue to be considered important by young and old.

\section{Blood Linkage}

Consanguinity (mixed marriage) is very common among Muslims in South Asia and Arabia. Among Pakistani Muslims, the current estimate is that around $75 \%$ of couples are in a family relationship, and around $50 \%$ are married to their first cousins. This is an increase in the

17 Yusuf Al-Qaradawi, The Lanful and the Probibited in Islam (al-halal wal haram fil Islam) (Indianapolis: American Trust Publications, 1999). 
generation of their parents, of whom only $30 \%$ are married to their first cousins. ${ }^{18}$

Consanguinity bestows many benefits, which, at least in part, explain its continuing appeal. For example, this allows in-depth knowledge of future marriage partners for sons or daughters - a very important consideration in the Muslim minority community where ordinary social networks that facilitate the search for the right partner may be lacking.

While doubts undoubtedly result in an increased frequency of family disorders with autosomal recessive patterns, ${ }^{19}$ assessing the relative contribution of consanguinity to high rates of congenital defects and perinatal deaths among Pakistanis is far from easy. Other factors that are important in the birth outcome debate include the high prevalence of deprivation among Muslims, difficulties with access to high-quality genetic and prenatal counseling, and risks that may be related to the care of pregnancy that are not culturally sensitive. ${ }^{20}$

\section{Challenges for Large Families}

In practice, usually, a new bride moves to her husband's household. These changes often occur, and problems in the new relationship between the bride and her in-laws are common. This transition is increasingly difficult where Muslims live as a minority because in many cases the pattern of migration has resulted in the fragmentation of large family structures. Many second-generation Muslim migrants grow up in nuclear families, do not have direct familiarity with the wealth and complexity of life in large family networks. ${ }^{21}$

In addition, even though there are religious teachings that encourage marriage at an early age, the secular tendency to get married not so early is too late among Muslims. Some observers say that increasing age limits a person's ability to adapt to change; adaptability is a feature of youth. Finally, and perhaps most important of all, Muslim

18 Aamra Darr and Bernadette Modell, "The frequency of consanguineous marriage among British Pakistanis," Journal of Medical Genetics 25, 3 (1988): pp. 186-190.

19 Sarah Bundey, et al., "Race, consanguinity and social features in Birmingham babies: a basis for prospective study," Journal of Epidemiology \& Community Health 44, 2 (1990): pp. 130-135.

20 Isobel Bowler, “'They're not the same as us': midwives' stereotypes of South Asian descent maternity patients," Sociology of Health \& Illness 15, 2 (1993): pp. 157-178.

21 Dhami and Sheikh, "The Muslim family: predicament and promise. 
youth in the West are faced with lifestyle choices that are not available in more traditional cultures. For some, the opportunities associated with individual freedom offered by nuclear family structures are far greater than the benefits of living in a large family.22

\section{Gender and Segregation}

Gender issues and, in particular, women's rights in Muslim culture, continue to generate a lot of media attention in the West. Muslim women are often described as inferior beings, desperately in need of liberation from Muslim patriarchal cultures that prevent their progress. Sex segregation, a practice driven by Islam, is often seen as evidence of oppression of Muslim women. ${ }^{23}$ Although there is certainly much that can be done to improve the position of women in Muslim culture, stereotypes made in the media leave many things stigmatized. This kind of misunderstanding is largely due to naive and simple efforts to transform western norms and values into women with very different histories and cultures. Detailed criticism of feminist positions is beyond the scope of this article; readers can refer to other references. ${ }^{24}$

As mentioned earlier, Islam clearly demarcates legitimate and illegitimate human relations. The community law exists to assist Muslims in complying with this framework. Segregation, therefore, exists primarily to minimize the possibility of developing illicit relations. Physical contact between members of the opposite sex is strongly discouraged, although this rule is rather loose if medical care is needed, for example. ${ }^{25}$ This framework explains why many prefer to meet same-sex doctors, especially in consultations that require genital examinations. On a practical note, if you need the help of an interpreter, the use of the same interpreter offers considerable benefits. The issue of gender segregation is one that must also be considered

\footnotetext{
22 Muhammad Anwar, Young Muslims in Britain: Attitudes, Educational Needs, and Policy Implications (Leicester: Islamic Foundation, 1994)

${ }_{23}$ Jan Goodwin, Price of Honor: Muslim Women Lift the Veil of Silence on the Islamic World (revised edition) (New York: Plume, 1995).

${ }^{24}$ Jamal A. Badawi, Woman Under The Shade of Islam: A Discourse on Woman's Issues (Cairo: El-Falah, 1997); also see Charis Waddy, Women in Muslim History (London: Longman, 1980).

25 Mustafa Yusuf McDermott and Muhammad Manazir Ahsan, The Muslim Guide: for Teachers, Employers, Community and Social Administrators in Britain (Leicester: Islamic Foundation, 1980).
} 
when planning health education campaigns, research interviews, and similar ventures.

\section{Indonesian Family Resilience and Social Change}

Efforts to create a strong and resilient family are also carried out by the Ministry of Religious Affairs through the Decree of the Minister of Religion of the Republic of Indonesia Number 3 of 1999 concerning the Development of the Sakinah Family Movement. This was followed up in 2009 and 2013 with rules regarding -PreMarriage Course or the so called "kursus pra-nikah". Khoiruddin Nasution and Syamsuddin Nasution in their article "Rules and Programs for Building Family Resilience: History of Legal Studies" divided this juridical effort into 4 stages. ${ }^{26}$ The first stage began since the birth of the BP427, which was formally formed on January 3, 1961, based on the Decree of the Minister of Religion No. 85 of 1961. The second stage was the birth of a series of Laws in 1974 consisting of (1) Law Number 1 of 1974 concerning Marriage, (2) Law Number 7 of 1989 concerning Religious Courts, (3) Government Regulations Number 9 of 1975 concerning Implementation of Law Number 1 of 1974 and (4) Government Regulation Number 10 of 1983 concerning Marriage and Divorce Permits for Civil Servants (PNS). The core of all the regulations in 1974 was the material of marriage legislation and litigation guidelines in the Religious Court. ${ }^{28}$

The third stage began in 1999 with the birth of the Development of the Sakinab Family Movement which was stipulated in the Decree of the Minister of Religion of Republic of Indonesia Number 3 of 1999 concerning the Development of the Sakinah Family Movement. This decree instructed that the Main Program for the Development of the Sakinah Family delegated to all the Heads of Provincial Office of Religion throughout Indonesia. For the purposes of the coaching,

26 Khoiruddin Nasution and Syamruddin Nasution, "Peraturan dan Program Membangun Ketahanan Keluarga: Kajian Sejarah Hukum," Asy-Syir'ab 51, 1 (2017): pp. 1-23.

27 One development of BP4 is an acronym change that occurs three times. First, in 1960, BP4 was an acronym for the Marriage, Disputes, and Divorce Advisory Board. Secondly, in 1977 it turned into a Guidance Agency, Marriage Advisory Board, Household Disputes. Third, at the National Conference (XIV) which took place from June 1-3, 2009, it changed to the Advisory Board for Marriage Development and Preservation.

28 Law 1/1974 on Marriage. 
there are many books that aim to be used as references and there is also an Exemplary Sakinah Family competition which is held once a year. The fourth stage lasted from 2009 until now. It is safe to say that this stage was triggered by an increase in the number of divorce and cohabitation. At this stage, the sakinah family paradigm starts early even before marriage using the strategy of Pre-Marriage Course for brides and grooms

Inevitably, the four juridical stages are influenced by the sociological and psychological situation that developed in his day. What was set in 1974 with the paradigm that developed in 2009, illustrates how countries try to be so involved in family protection. Also in 2009, through Law No. 52 concerning the Development of Population and Family Development, it was stated that the strength of national development was rooted in the family element as a microcommunity within the community and therefore the family prosperity was the basic foundation for the strength and sustainability of development. Conversely, vulnerable and scattered families weaken the foundation of the life of the state community.

Hence, there is a correlation between the birth of regulations regarding marriage and family to the resilience of families in Indonesia. ${ }^{29}$ Citing June S. Katz's research in 1978, the Indonesian Marriage Law of 1974 had succeeded in reducing divorce rates by around $70 \%$. In addition, the law also affected on the decrease of polygamy and irresponsible divorce cases among civil servants. The decrease is also boosted by the publication of PP No. 10 of 1983.30 However, it should be noted that these achievements could not represent the actual population figures, because the references are often limited to data recorded in the Religious Courts and BPS. ${ }^{31}$

In fact, the latest data in BPS every year from 2012 up to 2015 describes an increasing divorce rate. ${ }^{32}$ In 2013, the National

${ }^{29}$ Nasution and Nasution, "Peraturan dan Program Membangun Ketahanan Keluarga: Kajian Sejarah Hukum.

30 June S. Katz and Ronald S. Katz, "Legislating Social Change in a Developing Country: The New Indonesian Marriage Law Revisited," The American Journal of Comparative Law 26, 2 (1978): pp. 309-320.

31 Nasution and Nasution, "Peraturan dan Program Membangun Ketahanan Keluarga: Kajian Sejarah Hukum.

32 Badan Pusat Statistik, "Nikah, Talak dan Cerai, serta Rujuk, 2012-2015," Badan Pusat Statistik, 2015, accessed on 09 November, 2018, from https://www.bps.go.id/ dynamictable/2015/09/10/893/nikah-talak-dan-cerai-serta-rujuk-2012-2015.html 
Population and Family Planning Agency (BKKBN) said that divorce rates in Indonesia ranked highest in the Asia Pacific. ${ }^{33}$ In line with that, data from the Ministry of Religious Affairs states that from 2009-2016, divorce rates experienced an upward trend between 16-20\%.34 BPS itself said that from 2014 to 2016 the average divorce rate rose 3\% annually. ${ }^{35}$ Answering this latest challenge, it is necessary to look at the findings of many studies regarding the triggers of divorce in that year. In 2012, Rais found that the highest triggers for divorce were ongoing disputes. ${ }^{36}$ Budhy Prianto in 2013 said that the low marital commitment is the main cause of divorce. He also explains that the length of introduction, the age of marriage to the level of education actually does not guarantee the avoidance of couples from divorce. ${ }^{37}$ Divorce can easily occur because the bond base between partners is indeed weak. Muh Saidan analyzed the causes of divorce in Surakarta in 2013-2014 and found that the absence of maintenance is the main trigger for divorce. ${ }^{38}$ Armansyah Matondang, who analyzed the causes of divorce in Harapan Village, Dairi District, Medan, found young age as the highest cause of divorce. These researches show that there are indeed many factors that trigger divorce which are closely related to the context of the region and developing social conditions. ${ }^{39}$

33 Uly Siregar, "Beban Berat Menjanda di Indonesia," DW, 2018, accessed on 9 Nopember, 2018, from https://www.dw.com/id/beban-berat-menjanda-di-indonesia/ a-42745045-0

34 Tim Bina KUA \& Keluarga Sakinah Ditjen Bimas Islam Kemenag RI, Fondasi Keluarga Sakinah Bacaan Mandiri Calon Pengantin (Jakarta: Subdit Bina Keluarga Sakinah, 2017).

35 Badan Pusat Statistik, “Nikah, Talak dan Cerai, serta Rujuk, 2012-2015," Badan Pusat Statistik, 2015, accessed on 09 Nopember, 2018, from https://www.bps.go.id/ dynamictable/2015/09/10/893/nikah-talak-dan-cerai-serta-rujuk-2012-2015.html

36 Isnawati Rais, "Kedudukan Hukum Perempuan Dalam Undang-Undang Perkawinan (UUP)", Jurnal Legislasi Indonesia 7, 2 (2012).

37 Budhy Prianto, Nawang Warsi Wulandari, and Agustin Rahmawati, "Rendahnya komitmen dalam perkawinan sebagai sebab perceraian," Komunitas: International Journal of Indonesian Society and Culture 5, 2 (2013): pp. 208-218.

38 Muh Saidan, Analisis Faktor-Faktor Penyebab Terjadinya Perceraian Di Pemkot Surakarta Tabun 2013-2014 (Studi Kasus di Pengadilan Agama Surakarta) (Surakarta: Universitas Muhammadiyah Surakarta, 2015).

39 Armansyah Matondang, "Faktor-faktor yang mengakibatkan perceraian dalam perkawinan," JPPUMA Jurnal Ilmu Pemerintahan dan Sosial Politik Universitas Medan Area 2, 2 (2014): pp. 141-150. 
However, it is important to know this divorce pattern. What Rahmah Bourqia did for example by using Morocco as a study area found that the trigger for divorce in modern Muslim families was actually a culture-change. There are three aspects of change in the Muslim family; (1) family socialization mode, (2) changes in the status and role of individuals in the family, and (3) the position of women. ${ }^{40}$ The three aspects of this change, according to Bourqia, are triggered by globalization and modernization, which drives the birth of crossborder values and ideas. It has now become a challenge to remain a family with Muslim values that at the same time embrace modernity. Modernization has changed the pattern of children's education, which previously took place intact in the nuclear family, has now turned into social capital as measured by the social scale. Urbanization and industrialization also transformed communal families into urban families living in competition and are narcissistic. Furthermore, gender equality even affects the family paradigm as it encourages women to be very independent.

In his comparison between classical and modern families, Mohammed Haddad sees change as due to cross values. ${ }^{41}$ There was a clash of values which had been valid in Muslim families. Over the years, Muslim families have been defined in a patriarchal manner where fathers dominate and mothers obey. Men are the main holders of power and dominant leadership, moral authority, social rights, and property control. This clash of values according to Haddad actually happened in the Western family itself as the traditional family in the West was also patriarchal. The modernization had shaken the traditional attitude and produced a blurred division of roles. Thus, for Haddad, the clash of values between traditional and modern happens not only occur among Muslims but also in families in the West.

Traditional attitudes that classify roles and responsibilities between father and mother are inherent in all cultures. The father being responsible for living and the mother being responsible with managing domestic affairs is a fully believed definition and roles division. Through modernization, the division of roles loses its importance and

\footnotetext{
40 Rahma Bourqia and Susan Gilson Miller, In the Shadow of the Sultan: Culture, Power and Politics in Morocco (Vol. 31) (Cambriadge, Mass: Harvard University Press, 1999).

41 Mohamed Haddad, "The family as a Space of Social Integration in Islam," H. Reinfeld (ed.), Marriage, Family and Society: A Dialogue in Islam (German: KonradAdenauer-Stiftung, 2006).
} 
relevance. This is despite the fact that the demands submitted do not intend to eliminate each role but provide equal opportunities. It is the fact is that the emancipatory movement that developed together with modernization is perceived to be a trigger for freedom of sexuality, loneliness, social poverty and economic insecurity. According to Robert Stenberg, marriage needs, consisting of passion, intimacy, and commitment, ${ }^{42}$ are becoming blurred. The roles and responsibilities of men and women who are united encourage considerable individual efforts, where each person must be able to understand their partners without placing them in the division of roles.

John Gray calls this change "Role Mate versus Soul Mate". Role Mate is a traditional family form that unites together on awareness of roles, where men work and women perform domestic functions. Meanwhile, Soul Mate is a modern family that is formed on the need to complement each other's shortcomings and, as such, intelligence is needed in discovering the strengths and weaknesses of partners and in knowing how to complement those needs together. ${ }^{43}$ It is the effort in finding the meeting point in the "soul-mate" principle that, for John Gray, has triggered conflict in many modern families.

The culture that is driven by patriarchal culture has indeed interpreted biological differences to be indicators of appropriateness in behavior that ultimately lead to restrictions on rights, access, participation, control and the benefits of resources and information. ${ }^{44}$ However, gender equality does not mean becoming matriarchal. Gender equality arises on the basis of providing equal opportunities both for women and men to enjoy their rights as human, socially possess objects, opportunities, resources and enjoy the benefits of development outcomes. So, the manifestation of gender equality in the family is the formation of equal access, participation, control and benefits for both men and women.

The writings of Ray Pahl and Liz Spencer seem to be a reference for the transition between the traditional family model and the

\footnotetext{
42 Robert J. Sternberg, Triangulating Love in Oord, TJ The Altruism Reader: Selections from Writings on Love, Religion, and Science (West Conshohocken, PA: Templeton Foundation, 2007).

43 John Gray, Men Are From Mars, Women Are From Venus And Children Are From Heaven (London: Vermilion, 1999)

${ }^{44}$ Herien Puspitawati, Gender dan Keluarga: Konsep dan Realita di Indonesia (Bogor: IPB Press, 2012).
} 
encouragement of modern life. It suggests that a set of values does not replace the other; rather, the two values merge. ${ }^{45}$ Therefore, what must be done is to make choices among different sets of principles. To claim that the family in "traditional social thought" is not sustainable does not imply that social obligations based on hierarchy need to be abandoned. Rather, it merely suggests that those should be modified. The principle of hierarchy is still needed in the relationship between parents and children or also between partners in order to find harmony.

When secularization and individualism are used as references in family formation, according to McPherson et al., They will encourage feelings of loneliness. 46 If information technology is used as a communication, then intimacy can be disrupted. The distraction of passion through pornography worsens commitment. Marriage ties by relying on the values of modernization can weaken along with the poor communication between the two parties, even with their children. In the modern era, external loci, which, in traditional times became family values such as the convergence of society, community and law, now no longer can be relied upon.

The strength of religious dogmas and norms of society continues to decline, while atheism, agnosticism and individual spirituality are increasingly popular. De Lama et al, see this phenomenon as a phenomenon that needs to be corrected. However, everyone hopes to be able to build stable long-term relationships. As a therapist, De Lama introduces a "soul mates relationship" integrative approach. The 21 stcentury life challenges including individualistic, postmodern, consumerist, multicultural and global trends require an approach that maps conceptually relationships that touch all areas of a couple's life starting from fulfilling material and financial needs to strengthening intimacy, ideology, values, beliefs and spiritual orientation. Therefore, contemporary models for the development of successful partner relations must be holistic and integrate various conceptual and therapeutic frameworks. ${ }^{47}$

\footnotetext{
45 Ray Pahl and Liz Spencer, "Family, friends, and personal communities: Changing models-in-the-mind," Journal of Family Theory \& Review 2, 3 (2010): pp. 197-210.

46 Miller McPherson, Lynn Smith-Lovin, and Matthew E. Brashears, "Social isolation in America: Changes in core discussion networks over two decades", American sociological review 71.3 (2006): pp. 353-375.

47 De La Lama, et. al., "The soul mates model: A seven-stage model for couple's longterm relationship development and flourishing," The Family Journal 20, 3 (2012): pp.
} 


\section{Sex and Contraception \\ Sexual norms}

Sex in the context of marriage is a legitimate activity - an act of worship that deserves God's reward. Conversely, sex outside heterosexual marriage is deemed deviant and thus deserves punishment. ${ }^{48}$ In obeying the teachings of orthodox Christian Jews, homosexuality is considered sinful. However, differences are made between homosexual tendencies and the action itself. The first is accepted as long as it is not practiced. ${ }^{49}$

Relationships do exist among Muslims, although the probability is far lower than in some segments of western society. ${ }^{50}$ Those who operate outside the framework of Muslims often find themselves ostracized and held accountable for underestimated family names. The prospect of "going out" for Muslim homo-sex, therefore, is not realistic at this time.

Despite the positive attitudes towards sex, it remains a closed area for discussion. Cultural taboos dictate that sex must remain a personal matter between husband and wife. ${ }^{51}$ This explains, at least in part, why Muslims are reluctant to seek help for sexual problems and takes a long pause before seeing a doctor.

\section{Menstruation}

During menstruation, women are freed from some important religious rituals, such as ritual prayers, fasting, and pilgrimage (pilgrimage to Mecca). Sexual relations are also prohibited at such times. All other forms of physical contact between husband and wife, for example, hugging and kissing, are permissible. Menstruation, therefore, may have many social and psychological consequences. ${ }^{52}$ There are also many possible implications for clinical care. Women may be reluctant to see a doctor for gynecological symptoms, cervical

\footnotetext{
283-291.

48 Bowler, “'They're not the same as us': midwives' stereotypes of South Asian descent maternity patients.

49 Christopher Wayte, "Bible is disapproving of homosexual activity but not homosexual orientation," BMJ 319, 7202 (1999): pp. 123.

50 Colin Francome, Great Leap 2: A Study of Muslim Students (London: Middlesex University, 1994)

51 Yusuf Al-Qaradawi, The Lawful and the Probibited in Islam.

52 Dhami and Sheikh, "The Muslim family: predicament and promise.
} 
smear tests, or examination of contraception for fear of bleeding after a pelvic examination. Many Muslim women do not realize that this kind of traumatic bleeding is different from menstrual bleeding, and therefore, religious constraints do not apply. Education is needed both within the Muslim community and among professionals so that it is recognized the importance of the implications of genital tract bleeding.

Women can consult a doctor or family planning clinic to delay their menstrual period at a certain time. The most common situation is in the period before Hajj. For those who use combined oral contraceptive pills, pill packages can be safely recommended. ${ }^{53}$

\section{Indonesian Muslim Families and Millennials}

Combining the Gotman Method and Jungian Analytic Psychology concepts, De Lama describes the Pictogram for the Soul Mates Model. This model can be applied to counseling, therapy, and guidance interventions as well as relationship education, research and measurement, guidance and workshops as well as partner retreats. This model is built on holistic, developmental, and positive psychological conceptualizations of individuals and relationships, with the aim of optimizing marital status, religious affiliation and sexual orientation.

Table 1. Pictogram for the Soul Mates Model ${ }^{54}$

Table I. Correlating the Soul Mates Model to Maier's Pictogram

(Please note that most 20th century relationship models focus on the first four stages and provide little guidance for the crucial relationships phase that ensues after survival and family building needs are met.)

\Хर Stage I: Dating: the man and the woman

Stage 2: Commitment, the pair draws the circle of commitment around their relationship

0 Stage 3: Intimacy, the pair fills the circle of commitment with intimate knowing and love

Stage 4: Building a life, the pair draws the square, grounds their vision in physical reality

Stage 5: Integrating the shadow, the pair stuck in the square, must integrate shadow, rise upward.

Stage 6: Renewal, the pair draws the upward pointing triangle of higher aspiration, transcendence.

垱: Stage 7: Completion, sustainability, flourishing, the pair draws the larger circle of completion, sustainability, and flourishing around their relationship, engages in the great work.

This integrative model, according to De Lama et al., is indeed intended to build inclusive and postmodern relations; families that prioritize the values of equality and freedom. Religion-oriented family

53 John Guillebaud, The Pill (Oxford: Oxford University Press, 1991).

54 De La Lama, et. al., “The soul mates model: A seven-stage model for couple's longterm relationship development and flourishing. 
therapists and religious fundamentalist clients may reject some techniques in this therapy. ${ }^{55}$ Because this model is fully developed for modern family life patterns, they might have neglected the values developed by patriarchal tendencies. The approach to this integrative model is important to develop because modernity has influenced the millennial generation's mindset. It has even influenced many modern family forms, which are dominated by generations $\mathrm{X}$ and $\mathrm{Y}$ groups.

Generation X is a generation born in the range of 1956-1979, known as a generation of hard-working, obedient and loyal people while Generation Y is a generation born between 1980-2001. Generation Y is often referred to as the Millennial Generation because they grow and develop along with the development of technology and information. ${ }^{56}$ In the $\mathrm{X}$ and $\mathrm{Y}$ generations, two family concepts developed. Generation $\mathrm{X}$ is a transitional generation that lives in a traditional and modern era. In this generation, we find that the role mate paradigm as well as the soul mate paradigm has not been influenced by information technology except in the last 5 to 8 years. On the other hand, in generation $\mathrm{Y}$, the generation that lives between modern times and postmodern that develops along with information technology trend, the perception of soulmates is formed more thoroughly. These two generations also live in the fourth wave stage that is from 2009 to 2018.

Analyzing families in generations $\mathrm{X}$ and $\mathrm{Y}$ with the integrative approach of De Lama can be a comprehensive measure of family resilience. However, the De Lama integrative model cannot be used as a full measure for Islamic families, because the value of religious values is not used as a reference. For De Lama, religious values are the same as patriarchal values..$^{57}$

Interestingly, it is worth noting that, the concept of family in Islam does not mean patriarchal. Islam raises the value of marriage as a firm promise (misäqan galizāan), a proper order of association (mu'asyarah bil$\left.m a^{\prime} r u f\right)$. In addition, Islam also gives women inheritance rights as well as divorce rights $\left(k h u l u^{\prime}\right){ }^{58}$ Even though allowing polygamy, Islam

\footnotetext{
55 Ibid.

56 Bradley Jorgensen, "Baby Boomers, Generation X and Generation Y? Policy implications for defence forces in the modern era," foresight 5, 4 (2003): pp. 41-49.

57 De La Lama, et. al., "The soul mates model: A seven-stage model for couple's longterm relationship development and flourishing.

58 Tim Bina KUA \& Keluarga Sakinah Ditjen Bimas Islam Kemenag RI, Fondasi
} 
restrics polygamy and requires fairness. If we pay attention to the measurement of Family Resilience developed in Indonesia, we will find a concept of measurement that has not touched the substance. The Family Resilience Index conducted by the Ministry of Women's Empowerment and Child Protection (KPPPA) in 2016 for example, limit the variables and size indicators to external variables that has not touched the substance of the relationship in marriage. 5 variables 59 developed: ${ }^{6}$ (1) The Foundation of Family Legality and Integrity (2) Physical Resilience, (3) Economic Resilience, (4) Social Psychological Resilience and (5) Socio-cultural Resilience. So, they have not yet explained how the pattern of the relationship between a modern world husband and wife was developed.

The concept of the Sakinah family developed by the Ministry of Religion as an effort to reduce household failure also does not touch the important issues in improving the marriage paradigm. The five levels ${ }^{61}$ of sakinah family contained in the Decree of the Minister of

Keluarga Sakinah Bacaan Mandiri Calon Pengantin (Jakarta: Subdit Bina Keluarga Sakinah, 2017).

59 All family characteristics (indicators) are grouped into 5 dimensions and divided into 15 variables. The five dimensions (1) Family Legality and Structure have 3 variables: The Foundation of Legality, Family Integrity, and Gender Partnership, (2) Physical Resilience has 3 variables: Food and Nutrition Adequacy, Family Health, Housing Availability, (3) Economic Resilience has 4 variables: Family Residence, Family Income, Child Education Financing, and Family Financial Guarantee, (4) Social Psychology Resilience has 2 variables: Family Harmony and Compliance with Law, (5) Socio-Cultural Resilience has 3 variables: Social Concern, Social Relationship and Religious Obedience.

${ }^{60}$ BPS \& KEMENPPPA, Pembangunan Ketahanan Keluarga 2016 (Jakarta: Kementerian Pemberdayaan Perempuan dan Perlindungan Anak, 2016),

61 (1) Pre Sakinah Family; i.e. a family formed not through legitimate marriage provisions, can not fulfill basic spiritual and material needs (basic needs) at a minimum, such as faith, prayer, zakat fitrah, fasting, clothing, food, shelter and health, (2) Sakinah I Family i.e. families that are built on legitimate marriages and have been able to meet spiritual and material needs at a minimum but still cannot fulfill their social psychological needs, such as educational needs, religious guidance and their families, follow social-religious interactions with their environment, (3) Sakinah Family II ie families built on legal marriages and in addition to being able to fulfill their life needs have also been able to understand the importance of the implementation of religious teachings as well as religious guidance in the family, (4) Sakinah III family, namely families that can fulfill all the needs of faith, devotion, akhlaqul karimah, social psychology, and developer and his family but have not been able to become role models for their environment and (5) Sakinah III Plus family, which is a family that has fulfilled all the needs of faith, devotion and morality perfectly, psychological social 
Religion of the Republic of Indonesia Number 3 of 1999 concerning the Development of the Sakinah Family Movement ${ }^{62}$ are limited to categorizing families with food availability and involvement in the social life of the community. Although the Marriage Guidance module for brides and grooms has tried to touch on substantial matters such as managing the dynamics of marriage and family and managing conflict and family resilience, the description given is brief and not interpretive.

Re-interpretation and re-definition of integrative family concepts need to be done. What was done by Wald Muhammad al-ûmûdì in his Thesis "Ma'alim al-Usrah al-Muslimah fi al-Quran al-Karim" can be used as a reference. Al-ûmûdì developed 3 fundamental indicators, (1) Family Formation, (2) Rights and obligations in the family, and (3) Family problems and their resolution techniques. From these 3 indicators, Alûmûdī then developed several variables to become the basis for understanding the concept of family in the Koran. ${ }^{63}$

Although these indicators and variables are still normative, Alûmûdī's approach in assessing family meanings has taken into account considerable changes in family function due to modernity. Variables developed such as partner recognition skills, division of roles between husband and wife or father-mother, position and role of children and

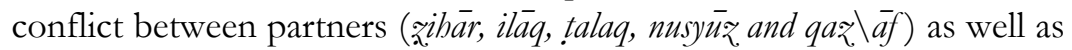
child conflict variables are substantial in an integrative approach. ${ }^{64}$ It's just that, these variables seem to be quite dogmatic and are not ready yet to be implemented in reality.

If De Lama developed an integrative approach by integrating the concepts of John Gottman and Nan Silver known as "The Seven Principles for Making Marriage Work"65, Indonesia with a majority of

needs, and development and can be a role model for their environment.

62 Decision of the Minister of Religious Affairs 3/1999 on Guidelines for the Campaign of the Creation Harmonious Family

63 W. M. al-'Āmûdī, Ma'älim al-Usrah al-Muslimah fi al-Quran al-Karim, Gaza: Islamic University of Gaza, 2010.

64 Ibid.

65 In the concept, Gottman developed 5 indicators of failure and 7 indicators of the success of marriage. The 5 indicators of failure are; (1) Criticism of character - not complaints, (2) Humiliation-sinism, sarcasm and, inconspicuous gaze, (3) Self defensesaying the problem is not me, that is you, (4) Stubbornness - rejecting criticism and tend to avoid problems and emotional (5) failed remedial efforts - lack of ability to manage conflict. The 7 indicators of success are (1) Knowledge and improvement of love maps, (2) Ability to find joy and admiration, (3) Need to be together rather than 
the Muslim population can then perfect it with the arguments of the Koran and Hadith. The interpretation of the al-Quran and Hadith propositions needs to be understood with enlarged approach; taking into account current sociology of society, family psychology and also communication-based on information technology. The interpretation of the arguments also cannot stop at normative concepts; it must also touch on implementative and affective issues.

\section{Threats and Challenges of Indonesian Families Narcotics in a religious family}

Technology is a sophisticated media in accessing various updated information so that all events are revealed in everyday life. Among the information is the phenomenon of rampant drug use that has increasingly spread throughout Indonesia. Our nation's moral decadence is increasingly dilapidated due several factors with lack of faith (spiritual values) is arguably one of the main one. Narcotics are increasingly blind in destroying the future of the nation's generation. According to the Kompas newspaper source, there were around 81,360 drug victims. This shows that drug has increasingly threaten Indonesian families. ${ }^{66}$

Family efforts in preventing drug use greatly determine the young generation in the future. Arguably, if the family environment is good, both the school environment and the playing environment, the youth will grow healthy and able to stay away from drugs. Among the efforts are drug control from school, the supervision of teacher and the parents towards the students in their daily interactions. There is indeed a need for good communication between students and teachers so that solutions can be created to overcome the problems that occur. In addition, it is necessary to collaborate with parents in supervising children during their times at home. A healthy home should have a harmonious family. The harmony means that there is a strong bond and smooth communication between father, mother, and child in a good family environment. Studies show that love, affection and time

\footnotetext{
leave each other, (4) There is a strong influence between partners, (5) Ability to solve problems, (6) Overcoming eternal problems, by finding the essence, (7) Shared meaning. See John Gottman and Nan Silver, The Seven Principles for Making Marriage Work: A Practical Guide from the Country's Foremost Relationship Expert (New York. Harmony Books, 2015).

66 Kompas, "Bahaya Narkoba," 25/4/2016.
} 
together with family is actually a power that can destroy the influence of drugs.

Another important note in this study is that many families are destroyed by trivial factors. Among the factors are the absence of child. This in fact can lead to divorce between husband and wife. According to Alfred Cahen, the high rate of divorce can be due to the status of the marriage, whether the husband and wife have children or not. Among couples who do not have children, $71 \%$ end up with divorce. Meanwhile, there is only $8 \%$ of married couples who have children end up in divorce. ${ }^{67}$

An immaturity is also another factor. According to the results of Glick and Norton's research in the United States, marriage carried out by teenagers in the teenage years are proner to divorce twice as large as the marriage that takes place between couples in their 20s. ${ }^{68}$ Alam, et al., conducted a study at Teknaf Bangladesh to see the effect of sociodemographic characteristics on the risk of divorce. Using the logistical model, it was concluded that socioeconomic status, illiteracy and young age at marriage increased the risks of divorce. This risk of divorce decreases with the length of marriage. Furthermore, it is also found that Polygamy and subsequent marriages have a greater risk of divorce. ${ }^{69}$

In relation to this issue, there is a research conducted by George Reniers on divorce and remarriage in rural areas of Malawi. The conclusion is that women who marry at a more mature age have a lower chance of divorce. It was also found that monogamous marriage was more stable than polygamous marriage. In addition, it was also found that labor migration also had an effect on marital instability. ${ }^{70}$ Another important finding is that there is indeed a quite significant impact of broken home on the psychology of children. There is arguably a correlation between the issue and the behavior of children

${ }^{67}$ Hendi Suhendi and Ramdani Wahyu, Pengantar Studi Sosiologi Keluarga (Bandung: Pustaka Setia, 2001).

68 Paul C. Glick and Arthur J. Norton, "Frequency, duration, and probability of marriage and divorce," Journal of Marriage and the Family 33, 2 (1971): pp. 307-317.

69 Nurul Alam, Sajal K. Saha, and Jeroen K. Van Ginneken, "Determinants of divorce in a traditional Muslim community in Bangladesh," Demographic Research 3, (2000).

70 Georges Reniers, "Divorce and remarriage in rural Malawi," Demographic Research 1,1 (2003): pp. 175-206. 
that, unfortunately lead to involvement with several negative problems such as free-sex and drug use.

Religion is a control in every culture that is not in accordance with human values. Thus, religion is the value of commodities in upholding a dignified civilization. Religion also tells families to guard against things that plunge humans into contempt, as God says in the Qur'an At-Tahrim verse 6.

From the verse it can be concluded that a good family is a family that is always concerned about family members, both in spiritual and social values.

\section{Family support network}

Another challenge encountered by families in this era is the issue of family support network. There is a case where a 28 -year-old woman consulted a doctor due to her suffering a lot of pain. It turns out that the "pain", showed a strong psychological component to her symptoms. When her notes were reviewed, it was found that she had 3 consecutive births; the last of which was only 6 months before at 36 weeks' gestation. The possibility of a stillbirth contributing to her condition is currently being raised. She acknowledged this and argue that that this is an issue she had to overcome on her own while in Pakistan she had the support of her extended family. Upon her return to England, she found herself more isolated and is struggling to overcome many problems along with this feeling. Counseling options have been discussed but rejected as she stated "What has happened to me is a test from God and something I will receive. The counselor cannot understand this". ${ }^{71}$

\section{Family responsibilities for members}

The issue of aging people never has been an issue in the previous era. This is due to the fact that there were never a question on how to manage the care for the elderly. However, nowadays, things are not what they used to be. There are more and more Muslims entering nursing homes, although there are still many, and arguably a large number, people who choose to continue taking care and live with their families until they die. To give illustration there is a case when an elderly Bengali man is recovering in hospital from an episode of

71 Dhami and Sheikh, "The Muslim family: predicament and promise. 
pneumonia. He is bound to bed as the result of an acute illness. When the family is approached by social services to discuss their placement in nursing homes, they explained that they preferred to care for him at home. With the support of doctors and social services, he can stay in the family home until his death a few years later. ${ }^{72}$

\section{Conclusion}

Several changes occur within the sociology of family in Muslim world and this includes Indonesian Muslim families. However, there are several things remain the same. Among the changes are related to culture-changes, with one of the main changes is the roles-division between man-woman/husband-wife/father-mother. This in turn has impact on the phenomenon of divorce. Nevertheless, there are also several values that are still held quite strongly among Muslim families and among them is the care of elderly.

The concept of nucleus family in Indonesian Muslim family is not only restricted to the couple and their son and daughter but it is extended and bigger. Family ties represent blood relationship responsibility. In the urban regions this concept may change. Nevertheless, the intimate relationship based on kinship and blood relationship remains strong. The couple relationship in the urban areas tends to change: from soul-mate towards role-mate. Hence, the loyalty to the family members may decrease gradually.

In addition, it also important to note that homosexuality remain taboo among Muslims and hence it is almost impossible for a Muslim to claim his homosexuality let alone for homosexual couples to be recognized as another form of family. Not only that, based on findings, Indonesian policy still limits the definition of family as those who are within marriage and hence limit possible other forms of families. []

\section{References}

\section{Books and Articles}

al-'Āmûdī, W.M. Ma'ālim al-Usrah al-Muslimah fi al-Quran al-Karim. Gaza: Islamic University of Gaza, 2010.

Alam, Nurul, Sajal K. Saha, and Jeroen K. Van Ginneken. "Determinants of divorce in a traditional Muslim community in Bangladesh". Demographic Research 3 (2000).

72 Ibid. 
al-' Asqalānī, Ibnu. Ḥ. Bulūghu al-Marrām min adillati al-Ahkām, M. Helmy, Trans. Bandung: Gema Risalah Press, 1991.

Al-Qardawi, Yusuf. The Lanful and the Probibited in Islam (al-halal wal haram fil Islam). Indianapolis: American Trust Publications, 1999.

Anwar, Muhammad. Young Muslims in Britain: Attitudes, Educational Needs, and Policy Implications. Leicester: Islamic Foundation, 1994.

Badan Pusat Statistik, "Nikah, Talak dan Cerai, serta Rujuk, 20122015". Badan Pusat Statistik, 2015, accessed on 09 November, 2018, from https://www.bps.go.id/dynamictable/2015/09/ 10/893/nikah-talak-dan-cerai-serta-rujuk-2012-2015.html

Badan Pusat Statistik. Statistik Indonesia 2017: Statistical Yearbook of Indonesia 2017. Jakarta: Badan Pusat Statistik, 2017.

Badawi, Jamal A. Woman Under The Shade of Islam: A Discourse on Woman's Issues. Cairo: El-Falah, 1997.

Balleyguier, Genevieve. "What is the best mode of day care for young children: A French study". Early Child Development and Care 33, 14 (1988).

Bourqia, Rahma and Susan Gilson Miller. In the Shadow of the Sultan: Culture, Power and Politics in Morocco (Vol. 31). Cambriadge, Mass: Harvard University Press, 1999.

Bowler, Isobel. “They're not the same as us': midwives stereotypes of South Asian descent maternity patients". Sociology of Health \& Illness 15, 2 (1993).

BPS \& KEMENPPPA. Pembangunan Ketahanan Keluarga 2016. Jakarta: Kementerian Pemberdayaan Perempuan dan Perlindungan Anak, 2016.

Bundey, Sarah, et al. "Race, consanguinity and social features in Birmingham babies: a basis for prospective study". Journal of Epidemiology \& Community Health 44.2 (1990).

Chernova, Zhanna. "New Pronatalism?: Family Policy in Post-Soviet Russia". Region: Regional Studies of Russia, Eastern Europe, and Central Asia 1, 1 (2012).

Cox, Frank D. and Kevin Demmitt. Human Intimacy: Marriage, The Family, And Its Meaning. Wadsworth: Cengage Learning, 2013. 
Darr, Aamra, and Bernadette Modell. "The frequency of consanguineous marriage among British Pakistanis". Journal of medical genetics 25, 3 (1988).

Decision of the Minister of Religious Affairs 3/1999 on Guidelines for the Campaign of the Creation Harmonious Family

De La Lama, Luisa Batthyany, et.al., "The soul mates model: A sevenstage model for couple's long-term relationship development and flourishing". The Family Journal 20, 3 (2012).

Dhami, Sangeeta, and Aziz Sheikh. "The Muslim family: predicament and promise". Western Journal of Medicine 173, 5 (2000).

Dockalova, B., et al. Sustainable Development Goals and Family Planning 2020. London: IPPF, 2016.

Doi, Abdur Rahman. Shariab: The Islamic Law. London: Ta Ha Publishers, 1984.

Francome, Colin. Great Leap 2: A Study of Muslim Students. London: Middlesex University, 1994.

Glick, Paul C. and Arthur J. Norton. "Frequency, duration, and probability of marriage and divorce". Journal of Marriage and the Family 33, 2 (1971).

Goodwin, Jan. Price of Honor: Muslim Women Lift the Veil of Silence on the Islamic World (revised edition). New York: Plume, 1995.

Gray, John. Men Are From Mars, Women Are From Venus And Children Are From Heaven. London: Vermilion, 1999.

Guillebaud, John. The Pill. Oxford: Oxford University Press, 1991.

Haddad, Mohamed. "The family as a Space of Social Integration in Islam." H. Reinfeld (Ed.), Marriage, Family and Society: A Dialogue in Islam. German: Konrad-Adenauer-Stiftung, 2006.

John Gottman and Nan Silver. The Seven Principles for Making Marriage Work: A Practical Guide from the Country's Foremost Relationship Expert. New York. Harmony Books, 2015.

Jorgensen, Bradley. "Baby Boomers, Generation X and Generation Y? Policy implications for defence forces in the modern era". Foresight 5, 4 (2003). 
Katz, June S. and Ronald S. Katz. "Legislating social change in a developing country: The new Indonesian marriage law revisited." The American Journal of Comparative Law 26, 2 (1978).

Kompas, "Bahaya Narkoba," 25/4/2016.

Law 10/1992 on Population Growth and the Development of Prosperous Family.

Law 52/2009 on Population Growth and the Development of Prosperous Family.

Law 1/1974 on Marriage.

Manzur, Yamal al-Din Muhammad Ibn. Lisan al-arab. Beirut, Lebanon: Al Dar al-Misriyya Li-l-ta'lif wa-l-tarhim, 1975

Matondang, Armansyah. "Faktor-faktor yang mengakibatkan perceraian dalam perkawinan”. JPPUMA Jurnal Ilmu Pemerintahan dan Sosial Politik. Universitas Medan Area 2, 2 (2014).

McDermott, Mustafa Yusuf and Muhammad Manazir Ahsan. The Muslim guide: for teachers, employers, community and social administrators in Britain. Leicester: Islamic Foundation, 1980.

McPherson, Miller, Lynn Smith-Lovin, and Matthew E. Brashears. "Social isolation in America: Changes in core discussion networks over two decades". American sociological review 71, 3 (2006).

Mubarok, Achmad. Psikologi Keluarga, dari keluarga sakinah bingga keluarga bangsa. Jakarta: PT. Bina Rena Pariwara, 2005.

Nasution, Khoiruddin and Syamruddin Nasution. "Peraturan dan Program Membangun Ketahanan Keluarga: Kajian Sejarah Hukum". Asy-Syir'ah 51, 1 (2017).

Newman, Jocelyn. Discussion Paper: The Challenge of Welfare Dependency in the 21st Century. Canberra: Department of Family and Community Services, 2000.

Pahl, Ray and Liz Spencer. "Family, friends, and personal communities: Changing models-in-the-mind". Journal of Family Theory \& Review 2, 3 (2010).

Prianto, Budhy, Nawang Warsi Wulandari and Agustin Rahmawati. "Rendahnya komitmen dalam perkawinan sebagai sebab 
perceraian". Komunitas: International Journal of Indonesian Society and Culture 5, 2 (2013).

Puspitawati, Herien. Gender dan Keluarga: Konsep dan Realita di Indonesia. Bogor: IPB Press, 2012.

Rais, Isnawati. "Kedudukan Hukum Perempuan Dalam UndangUndang Perkawinan (UUP)". Jurnal Legislasi Indonesia 7, 2 (2012).

Reniers, Georges. "Divorce and remarriage in rural Malawi". Demographic Research 1, 1 (2003).

Saidan, Muh. Analisis Faktor-Faktor Penyebab Terjadinya Perceraian Di Pemkot Surakarta Tahun 2013-2014 (Studi Kasus di Pengadilan Agama Surakarta). Surakarta: Universitas Muhammadiyah Surakarta, 2015.

Sternberg, Robert J. Triangulating Love in Oord, TJ The Altruism Reader: Selections from Writings on Love, Religion, and Science. West Conshohocken, PA: Templeton Foundation, 2007.

Suhendi, Hendi and Ramdani Wahyu. Pengantar Studi Sosiologi Keluarga. Bandung: Pustaka Setia, 2001.

Suyin, H. "Family planning in China". Developpement \& Civilisations, 47, (1972).

Tim Bina KUA \& Keluarga Sakinah Ditjen Bimas Islam Kemenag RI. Fondasi Keluarga Sakinah Bacaan Mandiri Calon Pengantin. Jakarta: Subdit Bina Keluarga Sakinah, 2017.

Uly Siregar, "Beban Berat Menjanda di Indonesia," DW, 2018, accessed on 9 Nopember, 2018, from https://www.dw.com/id/ beban-berat-menjanda-di-indonesia/a-42745045-0

Waddy, Charis. Women in Muslim History. London: Longman, 1980

Wayte, Christopher. "Bible is disapproving of homosexual activity but not homosexual orientation". BMJ 319, 7202 (1999). 